\title{
Agro-Ecological Assessment of Non-Traditional Export Crops in North East Trinidad
}

\author{
Nicole Ramlachan ${ }^{1 *}$, Ravi Renie${ }^{1}$, Kristy Samaroo', Jewan Ramcharitar ${ }^{2}$, Subesh Ramjattan² \\ ${ }^{1}$ Biosciences Agriculture and Food Technologies, University of Trinidad and Tobago, Centeno, Arima, Trinidad \\ ${ }^{2}$ Bridge of Hope Children’s Home, James Smart Village, Sangre Chiquito, Trinidad and Tobago \\ Email: *nicole.ramlacha n@utt.edu.tt
}

How to cite this paper: Ramlachan, $\mathrm{N}$. Renie, R., Samaroo, K., Ramcharitar, J. and Ramjattan, S. (2019) Agro-Ecological Assessment of Non-Traditional Export Crops in North East Trinidad. Agricultural Sciences, 10, 278-293.

https://doi.org/10.4236/as.2019.103024

Received: January 7, 2019

Accepted: March 10, 2019

Published: March 13, 2019

Copyright $\odot 2019$ by author(s) and Scientific Research Publishing Inc. This work is licensed under the Creative Commons Attribution International License (CC BY 4.0).

http://creativecommons.org/licenses/by/4.0/

\begin{abstract}
North-East Trinidad is a low income, underutilized, agro-ecological significant and agricultural community with great potential for producing non-traditional crops for domestic usage and export. Diversification is critical to agro-ecological transitions to ensure food security and nutrition while conserving, protecting and enhancing natural resources. The growing demand for agroecological and food security solutions suggest that efforts be made to utilize sustainable agriculture, and agro-ecological methods by utilizing available rural landscapes and communities in an effort to fulfill these demands. Surveys of sustainable agriculture, organic farmers and agro-ecological interests were conducted in the impoverished region of North-East Trinidad. Survey results reported over 180 farmers with $>1$ - 10 acres of available farmland supported a high agricultural production capacity. The highest average per capita for vegetables was tomato ( 2.3 acres), for tubers was yam (1.03 acres), and for tree crops was green fig (900 plants). Livestock production was limited with duck production being highest (165). There is an increasing earning potential for small farmers and leaseholders, from utilization of non-traditional export crops and expanding agro-ecological land usage, increasing sustainable agriculture production in the area.
\end{abstract}

\section{Keywords}

Sustainable Agriculture, Conservation, Organic Farming, Agro-Ecology, Economic Potential, Food Security

\section{Introduction and Literature Review}

Sustainability in the agricultural sector is of greatest importance in the $21^{\text {st }}$ century as it is an area in which one of the most critical fights for world's resources 
is taking place. Usually, the small farmers or fishermen are the ones that raise the issue of support for sustainable agriculture traditionally, especially since this has implicitly been a way of life for generations. Agro-ecology then naturally developed as a form of resistance to the Green Revolution and a way of defending small farmer knowledge and traditions. Trinidad's economy was built from early dependence on agriculture of the more traditional variety, with agro-ecological systems limited to more to rural "backyard" farmers. With the expansion and a push for more environmentally-friendly and resource-conserving sustainable agriculture, agro-ecology and non-traditional crop production has been embraced as a more popular option worldwide.

From the early $17^{\text {th }}$ century, Trinidad and Tobago was a sugar producing and exporting colony [1]. Sugar was the major cash crop and with the production and export of other traditional colonial-influenced crops such as coffee and cocoa, it provided an important source of revenue for the economy. As a monoculture system, sugar was profitable due to the significant demand for the commodity [1]. Caroni (1975) Ltd. was the lead in the sugar industry, later expanding production to citrus, rice, coffee and cocoa [2]. The latter was cultivated under more agro-ecological systems. Under colonial ruling, these crops were exported to Europe and to the United States to supply foreign markets [2]. However, the state owned industry was disbanded in 2003 due to mismanagement, increased market competition, change of interest to developing oil reserves and other conflicts [2].

Management of the 77,000 acres Caroni lands came under the control of a new state agency called the Estate Management and Business Development Company to distribute residential land and 2-acre agricultural plots [3]. As of 2006, only 6382 of these plots were distributed to farmers in 17 areas in Trinidad [3]. Most of the lands are no longer under agricultural production at the present time [2]. In addition, agriculture is no longer a substantive contributor to the national GDP of Trinidad and Tobago.

The oil and gas sector contributed the most to the nation's GDP, once it was developed more than 100 years ago. The agricultural sector was therefore neglected because of "Dutch disease", a phenomenon where a natural resource such as oil is so profitable to the country that all other sectors are less competitive and hence neglected [2]. However, with the world's constant fluctuating price of oil and the recent closures of the national oil refinery, agriculture can be further developed as an alternative industry to boost income and stabilize the economy.

Trinidad and Tobago and other CARICOM countries have a disadvantage of an increasing food import bill and rising global food prices (Food and Agriculture Organization [4]. According to the 2018 Budget Statement by the Government of Trinidad and Tobago, the food import bill was estimated at US\$8.91 billion over the period of 2006 to 2016 [5]. As a means to mitigate this high cost, the budget also includes as part of the diversification strategy, an agricultural financial support programme with grants of approx. US $\$ 15 \mathrm{k}$ to all new and exist- 
ing farmers [5].

Non-traditional agricultural commodities have been an untapped resource in our local, regional and international market. Carletto, Kilic and Kirk found that agricultural growth could be more effective in alleviating poverty compared to growth by secondary or tertiary sources of GDP [6]. Agro-ecology is also a growing sector in the demand for more sustainable agricultural production systems worldwide. There is a deficit of knowledge on non-traditional export crops regionally and almost none on the potential agro-ecological impact on increasing availability of agricultural products in Trinidad and Tobago.

The north-eastern region of Trinidad is generally characterized as low income agricultural communities situated within forested areas. The National Spatial Development Strategy for Trinidad and Tobago (2013) states that the Sangre Grande area and north-eastern region have the highest percentage (39.1\%) of individuals below poverty line in Trinidad and Tobago [7]. The stakeholders of agriculture within this region comprise of family and smallholder farmers who practice a mix of traditional and non-traditional crops and livestock production. The agro-ecological value of this area is great and poses a means by which, if harnessed correctly, this impoverished region can alleviate its low potential for income generation.

Due to the predominantly rural nature of developing countries, a focus on commercialisation of agriculture and diversification into valuable non-traditional export crops has often been advocated as a viable strategy for economic stabilization and growth stimulation in the agricultural sector as a step towards increasing household incomes [6]. Globally, there has been renewed interest in the practice of traditional agriculture [8]. In the year 2014, the United Nations instituted the International Year of Family Farming (IYFF) [8]. The declaration of the IYFF, affirmed the importance of family-managed farms and smallholder farms with regards to their significant contributions toward food production [8]. The diverse cropping systems of traditional farmers allow for greater diversity of local produce on the market [9]. Diverse cropping systems (including agro-ecological systems) allow for cost effective approaches for integrated pest management systems [9]. Yield stability and insurance effect are benefits of crop diversification since the farmer could rely on other crops if one fails. Sustainable agriculture systems can be effectively tied to agro-ecological models for farmers, especially those producing non-traditional crops, and expanded to export markets.

Although conventional agriculture has improved food production globally, incurrence of high economic and environmental costs due to heavy dependencies on off-farm inputs and use of specific crop varieties or hybrids that have been bred specifically to exploit high input conditions have been observed [9]. Therefore, improving the availability of local produce can reduce the importation of similar products as well as contribute to exportation of non-traditional crops that may also be considered exotic, derived from agro-ecological and traditional cultivation.

In a report for improving world food security, the FAO (2005) advised that 
the agricultural sector could contribute to substantial improvements in GDP, employment and tax revenue if well managed [10]. Here, as a first step, we have performed an agro-ecological assessment of production of non-traditional crops and livestock in a highly impoverished region, North-East Trinidad. This region historically was not part of the traditional agricultural areas under cultivation [2]. The United Nations Development Programme (UNDP)/Central Statistical Office (CSO) Trinidad \& Tobago ranked Sangre Grande and its environs, the third lowest in the country with respect to human development (0.551 HDIHuman Development Index) [11]. In regards to dimensions of health, education and income this region was also ranked among the lowest [11]. This study is the first of its kind to survey non-traditional crops in an area of agro-ecological significance with the potential to be a source of income for the region and if expanded, nation as a whole.

\section{Applied Research Method}

Field research was coordinated and conducted by students of the Biosciences, Agriculture and Food Science department at the University of Trinidad and Tobago. The team contacted and surveyed 639 farmers and householders in the North East Region of Trinidad (see Appendix 7.1 for maps), over a twelve (12) week period between June to August of 2016 (see questionnaire in Appendix 7.2). Sample size was determined by both the willingness and availability of all farmers within the study area to participate and the accessibility of the individual farms to the surveyors. Surveys were conducted in person and all data was collated and later analyzed using basic statistical software packages.

\section{Results and Discussion}

The north-eastern region of Trinidad surveyed in this study (Figure 1) presents an excellent snapshot of rural, agro-ecological production that can be utilized to bolster sustainable agricultural system in this area. The areas included Tamana, Kernaham, Plum Mitan, Fishing Pond, Cumuto and Manzanilla which are included in the Sangre Grande region. The 2011 Population and Housing Census calculated the population of Sangre Grande and its environs at $5.7 \%$ of the national population [11]. The region is the second least densely populated area ( 82 persons per square kilometre) of Trinidad and Tobago, significantly lower than the national average of $\sim 259$ persons per square kilometre [11]. The area for the study was selected due to the highly impoverished, low-income society with under-utilised available agricultural land, where the community consist of farmland with agro-ecological potential for non-traditional export crops. According to the Central Statistics Office as of 2016, only 3.35\% of the Sangre Grande municipality (surveyed region) has a registered business in operation, depicting a need for economic expansion [11].

The produce from these areas surveyed in this study are derived from cultivated crops, fruits from forest trees and livestock. Many of these farmed areas 


\section{Distribution of Areas Surveyed}

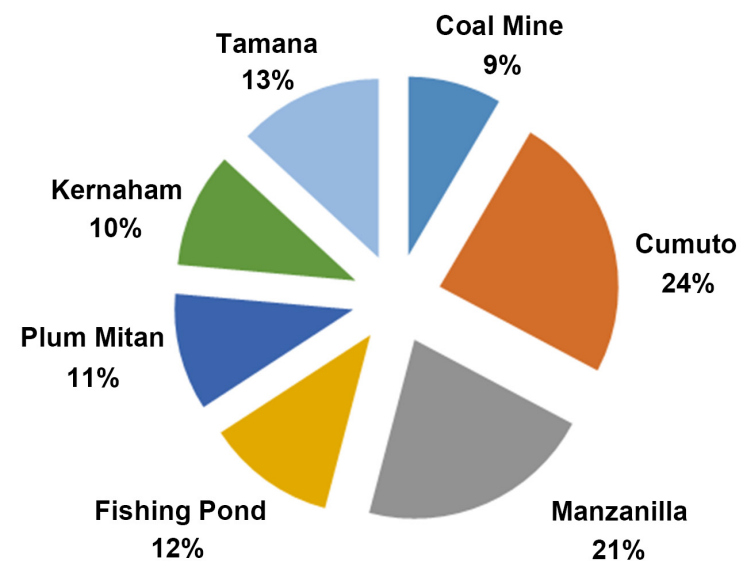

Figure 1. Chart showing distribution of areas surveyed in North-East Trinidad. Of the seven areas surveyed in the Sangre Grande area, the largest population of farmers was in Cumuto (24\%) and the smallest sample area was in Coal Mine (9\%). All areas surveyed were in the county of St. Andrew/St. David.

are managed by individuals from diverse backgrounds. Most of their farming practices limit the use of heavy pesticides or antibiotics as feed promoters. Table 1 describes the general statistics gathered on the farmers of North-East Trinidad. The majority of farmers belong to commercial households (433 farmers) while the rest belong to non-commercial households (206). We also found that most of the commercial farmers own $1-10$ acres of land for agriculture while the majority of non-commercial farmers had a farm size of less than 1 acre. Further, $67 \%$ of the commercial farmers produced vegetable crops as compared to non-commercial farmers who produced $43 \%$. The reverse was seen with fruit crops where $23 \%$ of the commercial farmers produced fruits while $67 \%$ non-commercial farmers produced fruits. Livestock contributed the least as an agro-ecological product in the entire region. Interestingly, there was a difference in the age of individuals operating commercial farm households versus those in the non-commercial farming households $(\mathrm{p}>0.05)$. The gender difference was also very significant with more males than females operating both commercial and non-commercial farming households.

The production capacity differed quite substantiably with the largest farming group having between $1-10$ acres under production. Figure 2 illustrates the total number of farmers that have $<1$ acres of land (209), $1-10$ acres (356) and $>10$ acres (54). The number of farmers with $1-10$ acres of land was six times that of farmers in possession of $>10$ acres. This data gives an indication of land availability for production of non-traditional crops, which is quite substantial, ranging upwards of 10 acres of agro-ecological areas under cultivation.

A total of 58 different non-traditional agricultural crops are produced in the survey area, with vegetables $(\mathrm{n}=378)$ then fruits $(\mathrm{n}=238)$ being the most produced crop (Table 2). We have listed all products in local terminology for ease 
Table 1. Descriptive statistics of sample smallholder farms.

\begin{tabular}{ccc}
\hline Variables & $\begin{array}{c}\text { Commercial households } \\
(\mathrm{n}=433) \\
(\% \text { farmers })\end{array}$ & $\begin{array}{c}\text { Non-commercial households } \\
(\mathrm{n}=206) \\
(\% \text { farmers })\end{array}$ \\
\hline Age (years $)$ & $45^{*}$ & 48 \\
Male & 73 & 64 \\
Female & 27 & 36 \\
Farm size $<1$ acre & 25 & 49 \\
Farm size 1 - 10 acres & 63 & 40 \\
Farm size > 10 acres & 10 & 06 \\
Vegetable crop farmers & 67 & 43 \\
Fruit crop farmers & 23 & 67 \\
Livestock farmers & 11 & 10 \\
Transport requirement & 52 & 35
\end{tabular}

Notes: ${ }^{\star}$ mean values between Commercial households and Non-commercial households are significantly different at the $5 \%$ level. ${ }^{* *}$ Mean values between male and female are significantly different at the $5 \%$ level.

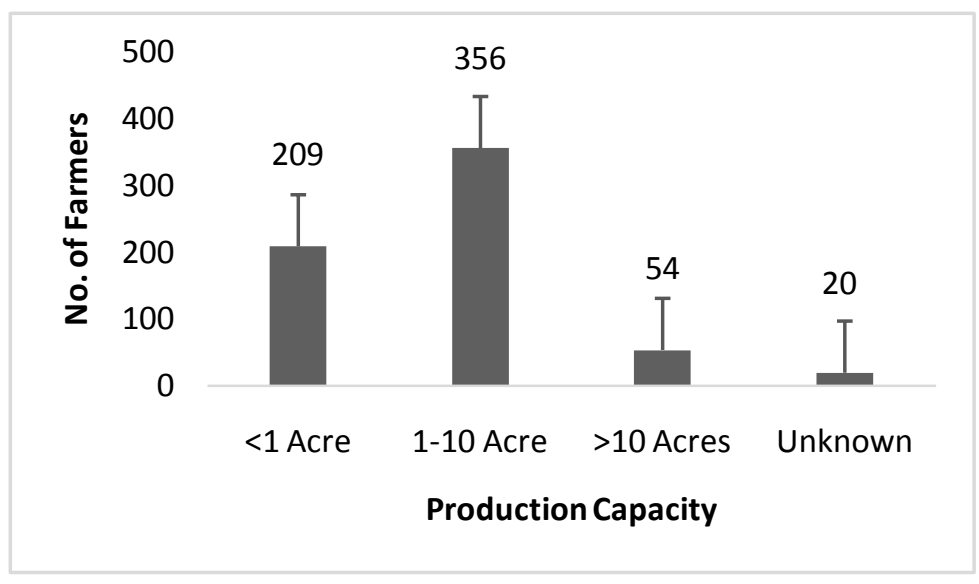

Figure 2. Farm acreage and production capacity. Acreage was scored as $<1$ acre, $1-10$ acres and $>10$ acres.

of comprehension by farmers. It is seen that the most produced crops are coconut (green) by 96 farmers, mangoes ( 85 farmers) and plantain ( 58 farmers).

Mangoes are very popular in Trinidadian diet, and there is a demand for it in the agro-processing market to produce grated, sliced and pulp mango product. Conversely, the least produced crops are barbadine, cashews, cherries and tangerine each being produced by a single farmer.

The area is a well known source of coconuts, due to the abundance of coconut trees brought to the area by early East Indian settlers. Worldwide, a growing demand for fresh coconut produce is being driven by recent trends in the global food and beverage sector and the health and beauty market. Yet, coconut is still a non-traditional export product in Trinidad and Tobago despite being utilized for copra and other value-added products in the past. This product in particular 
Table 2. Description of agricultural product in region. Product is delineated per type, total number of farmers and the total production capacities for each crop and livestock. Local names for all products are used for clarity during the survey and in this study.

\begin{tabular}{|c|c|c|c|c|}
\hline & $\begin{array}{c}\text { Type of } \\
\text { agricultural } \\
\text { product }\end{array}$ & No. of farmers & $\begin{array}{c}\text { Unit of } \\
\text { measurement }\end{array}$ & $\begin{array}{c}\text { Total No. of } \\
\text { acres/trees/plants } \\
\text { /heads }\end{array}$ \\
\hline \multirow{24}{*}{ Vegetables } & Bodi & 18 & Acres & 7.35 \\
\hline & Cabbage & 3 & Acres & 1.35 \\
\hline & Callaloo bush & 4 & Acres & 2.5 \\
\hline & Carailli & 12 & Acres & 13.76 \\
\hline & Cauliflower & 2 & Acres & 0.75 \\
\hline & Celery & 3 & Acres & 1.2 \\
\hline & Chive & 3 & Acres & 3 \\
\hline & Corn & 34 & Acres & 28 \\
\hline & Cucumbers & 53 & Acres & 57.35 \\
\hline & Hot peppers & 49 & Acres & 51.05 \\
\hline & Lettuce & 12 & Acres & 15.9 \\
\hline & Melongene & 8 & Acres & 5.85 \\
\hline & Ochra & 30 & Acres & 16.15 \\
\hline & Patchoi & 9 & Acres & 3.45 \\
\hline & Pigeon peas & 21 & Acres & 16.97 \\
\hline & Pimento & 18 & Acres & 17.45 \\
\hline & Plantain & 58 & Plants & 15,324 \\
\hline & Pumpkin & 20 & Acres & 31.75 \\
\hline & Seim beans & 6 & Acres & 3.6 \\
\hline & Shadon beni & 4 & Acres & 7.025 \\
\hline & Spinach & 5 & Acres & 302 \\
\hline & Squash & 2 & Acres & 1 \\
\hline & Sweet peppers & 4 & Acres & 4.5 \\
\hline & Tomatoes & 18 & Acres & 534.6 \\
\hline \multirow{10}{*}{ Fruits } & Avocado & 6 & Trees & 213 \\
\hline & Banana & 47 & Trees & 5591 \\
\hline & Barbadine & 1 & Acres & 0.25 \\
\hline & Breadfruit & 16 & Trees & 171 \\
\hline & Cashew & 1 & Trees & 2 \\
\hline & Chataigne & 12 & Trees & 47 \\
\hline & Cherries & 1 & Trees & 1 \\
\hline & Cocoa & 15 & Acres & 1166.5 \\
\hline & Coconut (dry) & 3 & Trees & 236 \\
\hline & Coconut (green) & 96 & Trees & 5050 \\
\hline
\end{tabular}




\section{Continued}

\begin{tabular}{|c|c|c|c|c|}
\hline & Five fingers & 1 & Trees & 25 \\
\hline & Grapefruit & 11 & Trees & 1449 \\
\hline & Green fig & 11 & Trees & 9922 \\
\hline & Lemon & 5 & Trees & 45 \\
\hline & Lime & 10 & Trees & 2271 \\
\hline & Mango & 85 & Trees & 5467 \\
\hline & Oranges & 53 & Trees & 11,355 \\
\hline & Passionfruit & 3 & Trees & 53 \\
\hline & Paw Paw & 8 & Trees & 1473 \\
\hline \multirow[t]{12}{*}{ Fruits } & Peewah & 3 & Trees & 71 \\
\hline & Plums & 3 & Trees & 10 \\
\hline & Pomegranate & 2 & Trees & 11 \\
\hline & Pommecythre & 3 & Trees & 17 \\
\hline & Pommerac & 2 & Trees & 26 \\
\hline & Portugal & 21 & Trees & 9034 \\
\hline & Sapodilla & 2 & Trees & 4 \\
\hline & Sorrel & 21 & Acres & 22.4 \\
\hline & Tangerine & 1 & Trees & 13 \\
\hline & Watermelon & 25 & Acres & 67.1 \\
\hline & Cassava & 20 & Acres & 16.13 \\
\hline & Dasheen & 9 & Acres & 5.6 \\
\hline \multirow[t]{4}{*}{ Tubers } & Eddoes & 2 & Acres & 1 \\
\hline & Sweet potato & 3 & Acres & 2.5 \\
\hline & Yam & 3 & Acres & 3.1 \\
\hline & Ducks & 4 & Heads & 165 \\
\hline \multirow{3}{*}{ Livestock } & Sheep & 1 & Heads & 25 \\
\hline & Cattle & 2 & Heads & 4 \\
\hline & Goats & 3 & Heads & 49 \\
\hline
\end{tabular}

can serve to bolster the farmers in the area if local and export markets for fresh coconut water (green coconuts) can be sought.

Many of the vegetables are non-indigenous and were brought by Indian settlers to the area in the 1800's and used in popular meal preparations. For example, Bodi (type of green bean) (18 farmers), callaloo bush (related to spinach produced by 4 farmers), carailli (bitter melon produced by 12 farmers) and Shadon beni (related to Cilantro produced by 4 farmers). The largest numbers of farmers were involved in cucumber (53), hot peppers (49) and plantain production. However, the largest acerage under production was tomatoes (534.6 acres) and Spinach (302). 
Most of the non-commercial farms were "backyard" farmers producing for their own usage or selling in the local community or local markets. Despite the total production capacity of citrus was also quite high in this area. Oranges (11,355 trees) and Portugal (9034 trees) seem to be the most cultivated citrus trees, followed by Lime (2271 trees) but very few Lemon varieties (45) were noted in the area. Tangerine was grown by only 1 farmer with 13 trees grown on his farm (Table 2).

There were 22.4 acres of sorrel being cultivated, with this being a very popular fruit used in seasonal drinks in Trinidad and Tobago. Green fig (9922 trees) and banana (5591 trees) also represented a large portion of fruits, which are both in high local demand. Watermelon was being cultivated by 25 farmers with approximately 67.1 acres under cultivation.

Tubers were also produced in this area, which is not surprising since these are consumed in large quantities in the local cuisine. In particular cassava represents a large portion of the cultivation with 16.13 acres being under cultivation by 20 farmers.

Livestock generally did not play a very large role in agriculture in the area, but mixed farms and non-commercial farms tended to have a few animals. The largest were some duck and goat farmers producing 165 and 49 heads respectively.

Figure 3 shows the average production capacity of vegetable crops in the areas surveyed. Tomatoes have the highest average production capacity with 2.03 acres compared to cauliflower and patchoi whose average production capacities are both 0.38 acres respectively. This illustrates the potential contribution of tomatoes for the local and export market as well as for secondary processing.

The average production capacity of tubers is presented in Figure 4. Yam has the highest average production capacity (1.03 acres) while eddoes have the lowest ( 0.5 acres). In addition, the average amount of green fig plants produced surpasses the capacity of all other tree crops. This capacity is about 150 times the amount of the lowest average capacity which was found to be pomegranate and pommecythre (avg. 6 trees).

The total and type of tree crops being produced in the area is shown in Figure 5. In addition, the average amount of green fig plants produced surpasses the capacity of all other tree crops. This capacity is about 150 times the amount of the lowest average capacity which was found to be pomegranate and pommecythre (avg. 6 trees). The total head count of livestock is seen in Figure 6, which was mostly non-commercial with the exception of poultry. Livestock are not produced on a relatively small scale, with the larger numbers (per head) among commercial farmers Ducks were the most raised livestock (165 heads) compared to cattle which were the least reared (4 heads).

\section{Conclusions}

One of the major challenges purporting the need for sustainable food and agricultural systems is the anticipated increase in the demand for food due to 


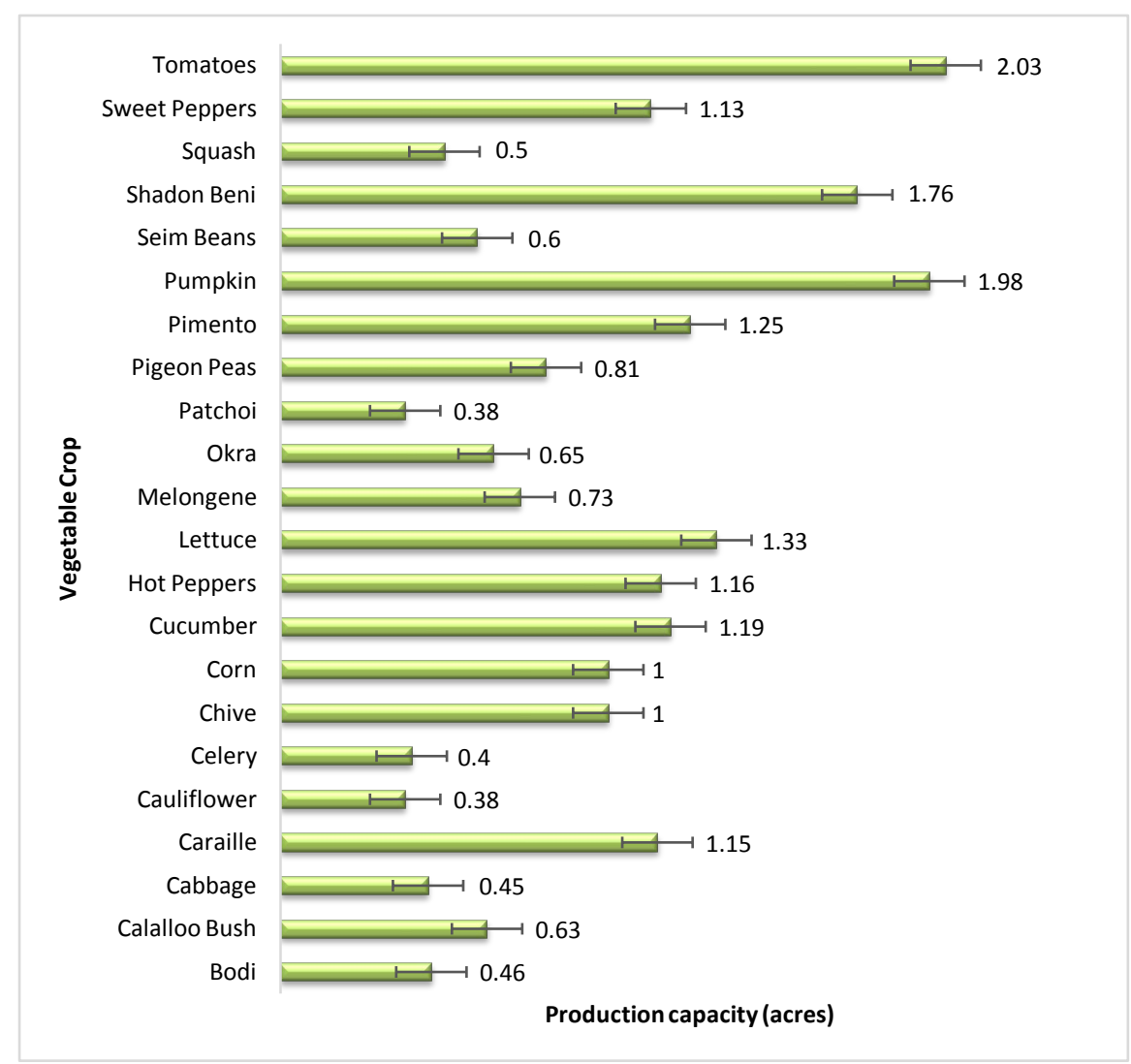

Figure 3. Average production capacity of vegetable crops of 22 different vegetable crops grown by both commercial and non-commercial farmers in the survey area.

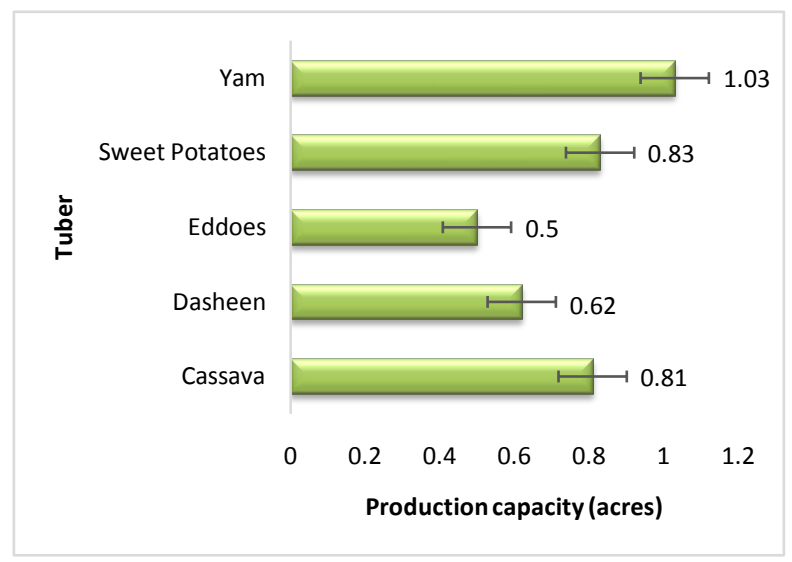

Figure 4. Average production capacity (acres) of tubers grown in the study region.

exponential population growth both locally and globally [12]. The Trinidad and Tobago government has outlined food security as a priority in the country's 2030 vision with a strong focus on re-engineering the agriculture sector to liberate the nation from dependence on imported foods [13]. There is also a critical need to preserve land as natural ecosystems to help protect as much of our threatened biodiversity and reduce the negative environmental impact from 


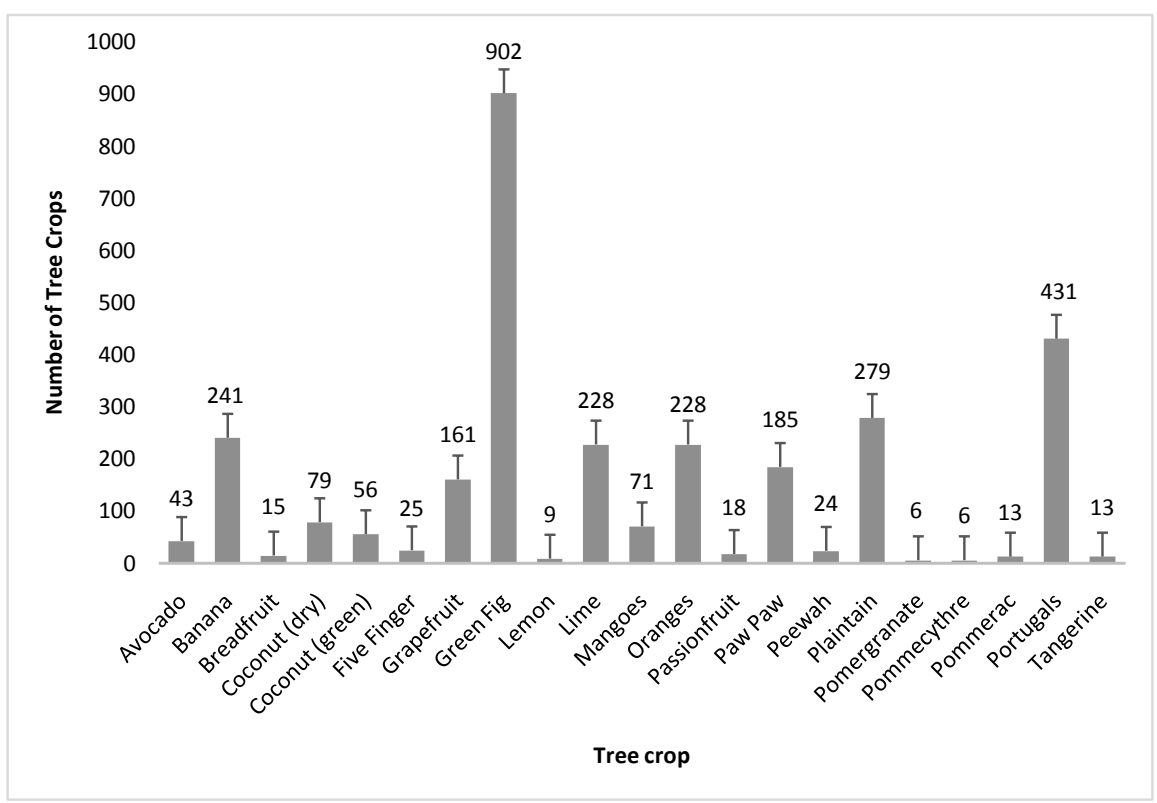

Figure 5. Average production capacity (trees) of the twenty-one (21) types of tree crops grown in the surveyed area by all farmers. The local names are used for clarity during the survey and in this study.

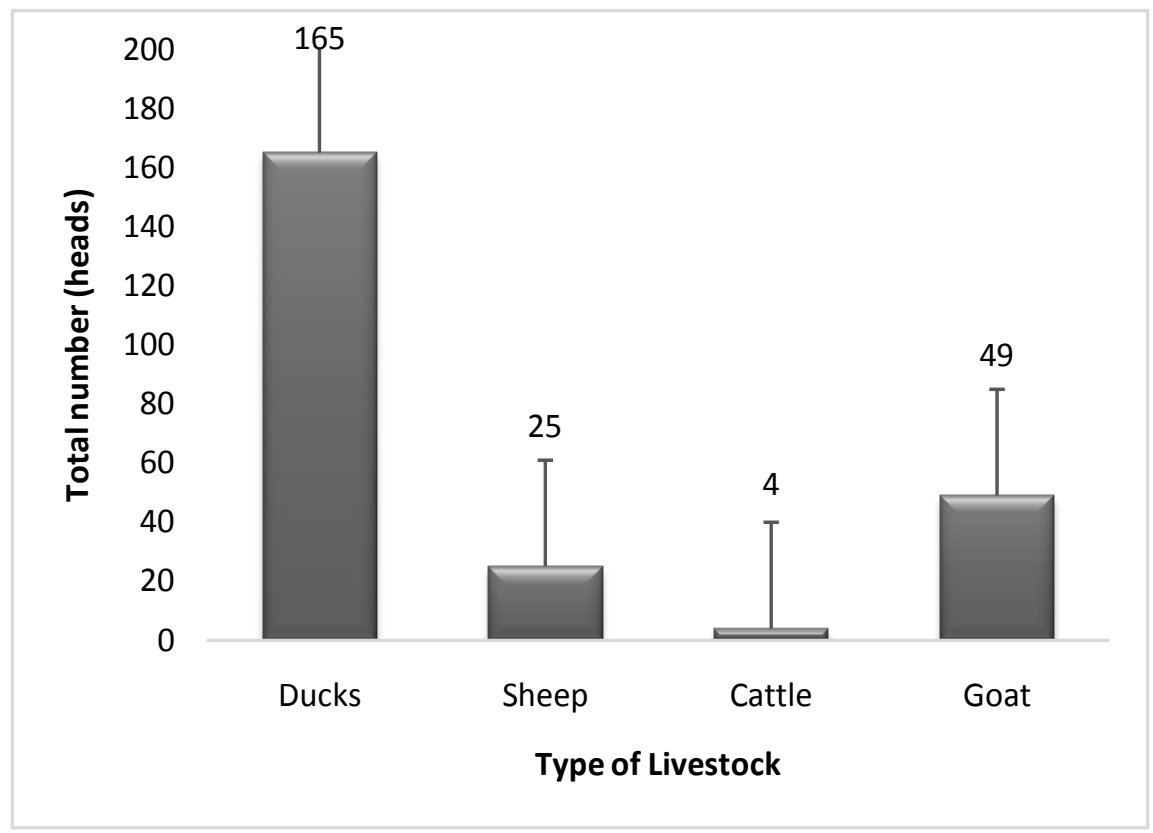

Figure 6. Total headcount of livestock reared by all farmers surveyed.

intensive and traditional agriculture as possible [12]. Agro-ecology involves resource-conserving production systems [12] This study recognized an effort by most farmers to abstain from harmful abuse of agro-chemicals and feed promoters. The practice of sustainable organic farming of non-traditional export crops within the study region supports the national development vision.

The role of agro-ecology has become more critical to develop sustainable ag- 
riculture systems, especially in rural and impoverished communities. A recent strategy to reduce rural poverty and combat food insecurity is to focus on commercial agriculture and diversification into non-traditional export crops [14] as a means of contributing to sustainable agricultural systems. More recently, sustainable agriculture was debated in the context of food sovereignty, a concept presented at the World Food Summit in 1996 [15]. Agro-ecology, which respects the rights of communities, as well as integrates the roles of different elements of nature into a model for sustainable agricultural systems, is proposed as the intersection of those concepts.

This study shows the existing agricultural produce and available land under cultivation in North East Trinidad. Agriculture is the predominant land use within the study region [11]; however, these data show that there is a valuable agro-ecological and untapped resource in this area, especially for non-traditional crops. There is a large amount of acreage producing both traditional and non-traditional crops as well as livestock. This area is an excellent microcosm for agro-ecological assessment fulfilling the purpose of moving towards more sustainable agricultural system in this region which would have additional value increasing household incomes within this impoverished region.

This research can also be conducted within other low income rural communities in efforts to expand agro-ecological methods in sustainable agriculture in the desire for diversification by increasing the contribution to the GDP from agriculture in Trindad and Tobago and if expanded, regionally. Future implication of this research is the development of an agricultural production system in the rural north east region of Trinidad through the creation of a non-profit marketing/food hub as a measure to create better access to the market for all types of farmers, particularly small-scale producers. There is a demand for increasing agriculture and earning potential for small farmers and leaseholders from utilization of non-traditional export crops and expanding agro-ecological land usage, increasing sustainable agriculture production in this area.

\section{Acknowledgements}

We wish to thank Ms. Ariel Pantin, Mr. Kyle Goberdhan, Ms. Khristy Beharry-Renie, the students of Biosciences, Agriculture and Food Technology department of the University of Trinidad and Tobago and the team at the Bridge of Hope, Children's Home in Sangre Chiquito, Trinidad for their very valuable contribution towards this research.

\section{Conflicts of Interest}

The authors declare no conflicts of interest regarding the publication of this paper.

\section{References}

[1] Eccles, K.E. (2017) The Sugar Heritage Village and Museum Project: Salvaging the 
History of the Trinidadian People. Caribbean Library Journal, 3, 39-49.

[2] Ballayram, Lawrence, B. and Henry, F. (2015) Food Security and Health in the Caribbean Imperatives for Policy Implementation. Journal of Food Security, 3, 137-143.

[3] Allard, A.L. (2012) The Contribution of Small Farms and Commercial Large Farms to the Food Security of Trinidad and Tobago. College of Liberal Arts \& Social Sciences Theses and Dissertations. Paper 129. http://via.library.depaul.edu/etd/129

[4] Food and Agriculture Organization (FAO) (2013) CARICOM Food Import Bill, Food Security and Nutrition. Issue Brief 5.

[5] Imbert, C. (2017) Budget Statement 2018-Changing the Paradigm: Putting the Economy on a Sustainable Path. Ministry of Finance, Government of Trinidad \& Tobago.

[6] Carletto, C., Kilic, T. and Kirk, A. (2009) Non-Traditional Export Crops in Guatemala: Short-Term Tool or Long-Term Strategy for Poverty Alleviation? 111 EAAE-IAAE Seminar "Small Farms: Decline or Persistence", University of Kent, Canterbury, 26-27 June 2009.

[7] Ministry of Planning and Sustainable Development, Government of Trinidad \& Tobago (2013) National Spatial Development Strategy for Trinidad \& Tobago: Core Strategy and Regional Guidance. A Planning Framework to Govern Physical Development.

[8] Spoor, M. (2015) Rural Development and the Future of Small-Scale Family Farms. Food and Agriculture Organization of the United Nations, Rome. Rural Transformations, Technical Papers Series \#3.

[9] Njeru, E.M. (2013) Crop Diversification: A Potential Strategy to Mitigate Food Insecurity by Smallholders in Sub-Saharan Africa. Journal of Agriculture, Food Systems, and Community Development, 3, 63-69. https://doi.org/10.5304/jafscd.2013.034.006

[10] FAO/SOFI (2005) Food and Agriculture Organization of the United Nations; Rome, Italy: 2005. The State of Food Insecurity in the World (SOFI).

[11] Kairi Consultants Limited (2016) Municipality of Sangre Grande-Local Area Economic Profile (Final Report).

https://rdlg.gov.tt/wp-content/uploads/MLG-Final-Sangre-Grande-LAEP-Report-2 0160229.pdf

[12] Donovan, J. and Poole, N. (2008) Linking Smallholders to Markets for Non-Traditional Agricultural Exports: A Review of Experiences in the Caribbean Basin. Inputs for Strategy Formulation by "EU-ACP All Agricultural Commodities Programme". Food and Agriculture Organization of the United Nations-AAACP Paper Series No. 2.

[13] Government of Trinidad \& Tobago Vision 2030. The National Development Strategy of Trinidad \& Tobago 2016-2030.

[14] Méthot, J. and Bennett, E.M. (2018) Reconsidering Non-Traditional Export Agriculture and Household Food Security: A Case Study in rural Guatemala. PLoS ONE, 13, e0198113. https://doi.org/10.1371/journal.pone.0198113

[15] FAO (1996) Food and Agriculture Organization of the United Nations; Rome, Italy: 1996. Report of the World Food Summit, 13-17 November 1996. 


\section{Appendix 7.1-Maps of Trinidad Showings Areas} (North East) Surveyed
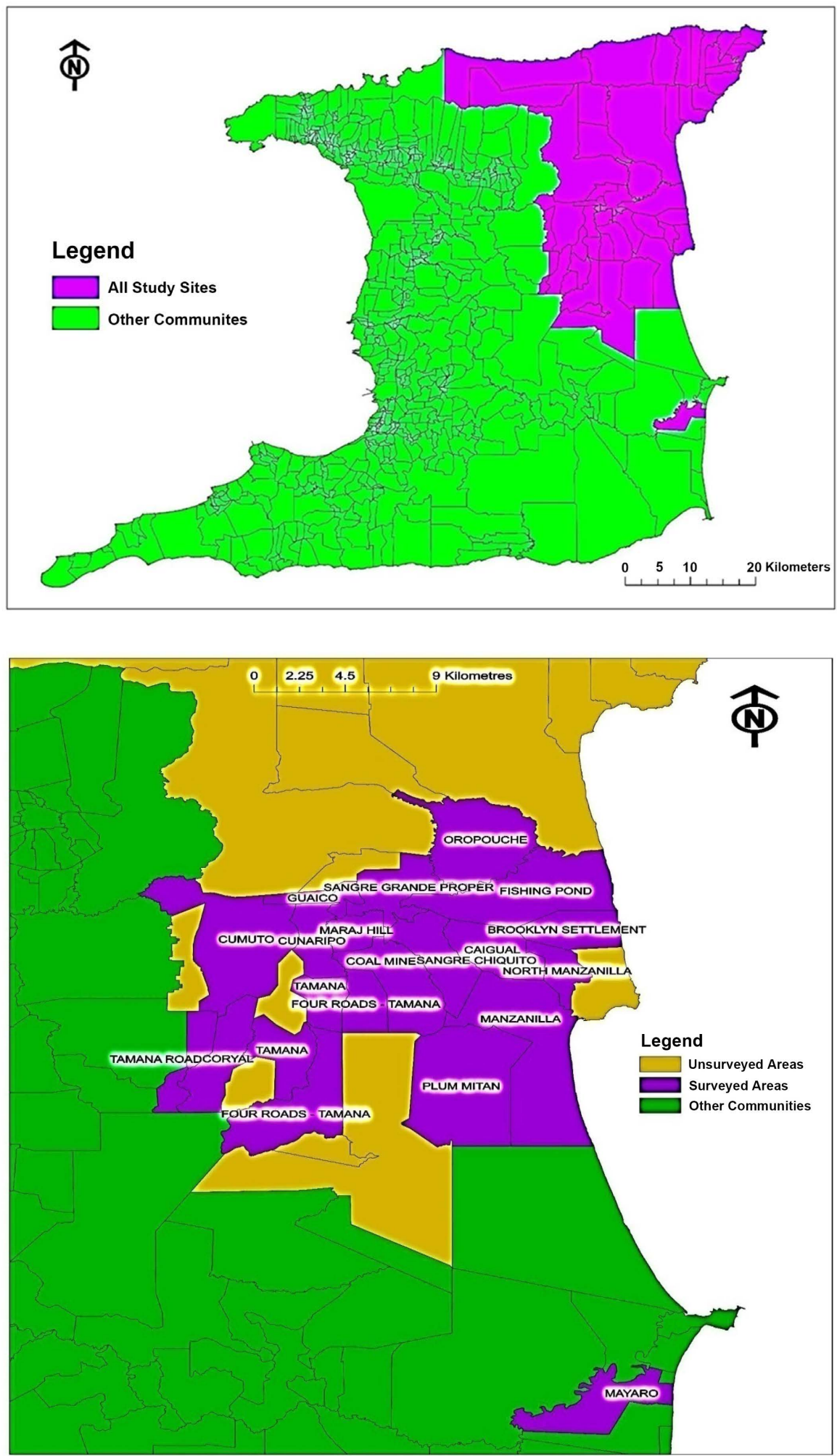


\section{Appendix 7.2-Questionnaires Used for Surveys Conducted}

\section{Questionnaire for farmers and growers}

Name:

Age:

Address:

Gender:

1) Which of the following do you grow or produce?

- Milk \& Dairy Products

- Livestock

- Vegetables Crops

- Fruit Crops

- Other, please specify

2) What is the size of your farm?

- $<1$ Acre

- 1 - 10 Acres

- $>10$ Acres

3) Are you currently selling your products to any of the following local/regional customers?

- Individuals

- Institutions (schools, hospitals, etc.)

- Restaurants

- Retail Stores

4) If no, would you consider selling your products locally/regionally?

- Yes

- No

5) What type of farmer are you?

- Backyard

- Small Scale

- Medium Scale

- Large Scale

6) Describe your market type:

- Wholesale

- Retail

- Both (Wholesale/Retail)

- Neither

7) Which of the following problems do you experience in relation to your farm production?

- Limited or no access to reliable water supply

- Limited or no access to electricity

- Ability to have regular and consistent supply of inputs 
- Predial larceny

- Other, please specify

8) Which of the following barriers exist to selling your products locally/regionally?

- Finding local/regional customers

- Not enough potential revenue from local/regional markets

- Lack of understanding of selling directly to customers

- Other, please specify

9) Do you require transport to be able to supply your produce to the market?

- Yes

- No

10) What type of crops do you cultivate and how much do you produce?

11) Do you generate income from your produce?

- Yes

- No 